\title{
The Historical Process of Fandom as a Participatory Pastime: Film Discourse in Newspapers from 1911 to 1918
}

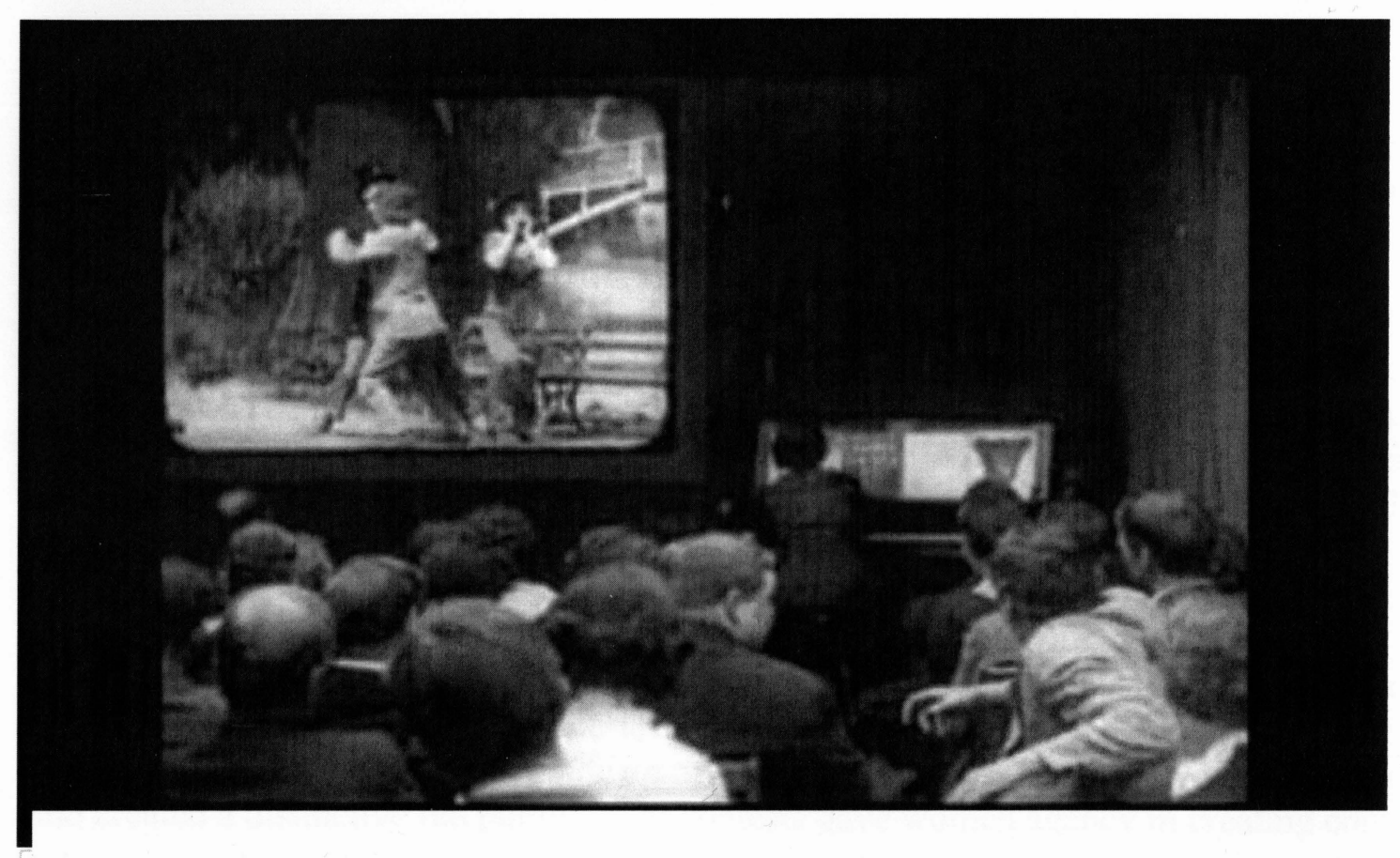

Image via Getty circa 1915

The Major Research Paper is submitted in partial fulfillment of the requirements for the degree of Master of Arts Joint Graduate Program in Communication \& Culture Ryerson University - York University Toronto, Ontario, Canada 


\begin{abstract}
"Who Will Be Ruth?" was a headline that dominated small town newspapers from 19151918. This headline corresponded with a contest that targeted young women to participate in the new national pastime of cinema by having local women vie for the roles in a film with citizens voting for their favourite woman to play the lead character of Ruth. The "Who Will Be Ruth?" contest became a local phenomenon, which garnered tens of thousands of votes in each town the contest ran. The contest exemplifies the film contest trend that occurred in newspapers from 1911-1918, which elicited audience participation in the creation of film content. Movie contests reveal an early participatory culture, which contradicts critical theory's notion of a passive audience. Mass produced cinema in fact actualized publics that participated in the creation of the very content they consumed. The formation of movie fans can be studied by exploring early participation in collective practices, as reflexive circulation of discourse is integral to the creation of a public (Warner, 2002). My research involves studying three distinctive film contests that demonstrate the historical process of creating fandom through the use of newspaper texts. The transformation of film into American mass culture in the 1910s is directly connected to fan groups who were largely made up of female fans who both legitimized filmgoing and created a distinctive fan public. Film contests gave women agency in creating content for mass culture before voting rights were universal. An exploration of movie contests from 1911-1918 will provide new insights into the relationship between participatory cultures, aesthetic objects and discourse.
\end{abstract}




\section{Introduction}

On July 14, 1915 a prominent story in the "For Interest of Women" section located in the Times Democrat of Muskogee, Oklahoma boasted "Vain Beauty: A Pest Says Most Beautiful Girl Who Soon May Be A Movie Star". The story is about Ruth Purcell, a stenographer, who recently won a prospective movie star contest held by the Universal Film Company. The article portrays Ms. Purcell as a reluctant movie star who does not consider herself a beauty and would rather continue her "useful" work as a stenographer. While Ms. Purcell was a reluctant movie star the article demonstrates the relationship between newspapers, film and fandom, which emerged during 1910s. It was during this period that film companies targeted average women to become part of the filmmaking industry, which was reflected in local stories in newspapers across America. In the case of the Universal Film Company's contest, 60 women were shortlisted in a contest to find the next big film star and all traveled west from various states. The Universal Film Company used the contest as an advertising mechanism for its movies, and is representative of many similar advertising incentives of the period. I came across the contest while researching early movie pages in North American newspapers and discovered the phenomenon of the film contests found in newspapers addressing female newspaper readers. Contests like the Universal Film Company's movie star contest made women active participants in the creation of movie fandom.

Film was transformed from a cheap amusement to mainstream popular culture in the first decade of the $20^{\text {th }}$ century and this transformation can be distinctly related to movie fandom and the fan discourses found in newspapers. Mass produced cinema actualized imagined communities that participated in the creation of the very content they 
consumed, at both the local and national level. As Benedict Anderson theorizes, imagined communities are developed through the circulation of discourse. In this sense, movie fandom was created as a mass reading public through various engagements with local newspapers. By 1911, newspapers across America began to mandate film-related contests, almost exclusively for and about women. The gendered dynamic of early movie fandom gave women agency before political voting rights were universal. Early movie contests demonstrate the process behind the creation of dynamic fans, who sometimes even participated in the creation of film content. Contests ran in large cities such as Pittsburg and smaller cities such as Lima, Ohio. All these contests illustrate the dynamic of early fan discourses as they encouraged contributions to media in order to create a dynamic fan public.

My study was conceived as a way to explore how the circulation of discourse influenced the creation of a distinct film public. I started out my search by looking through early movie pages in the 1910s as it was during this time period that distinct movie pages were developed outside of newspaper vaudeville listings. I noticed the gendered dynamic of these early pages as they often clearly targeted to women. I also noticed that these early movie pages included various trivia and movie star ranking contests. In order to conduct my research, I utilized Internet archives to further explore the phenomena of movie contests across the continent.

Internet data collection has become a very useful tool for historical research, and because of the advent of digital archives I was able to do an exhaustive search throughout various newspaper collections including Newspaper Database, Historical Abstracts and Google News Archive using the terms "film", "movie" and "photoplay contest". The 
word "contest" is derived from the Latin contestari meaning to bring an action into the realm of law. The term contest thus denotes "action" that is both a legal and a public action. Contests by their very nature are participatory and are thus a precise method to study the historical process of participatory cultures. Unlike other terms that indicate popularity rankings such as ballot or vote, the word "contest" suggests active participation, and was the most useful term in my search. "Contest" also conjures up the notion of actively contesting power. This notion of contesting power will be later explored in terms of movie contests as a means of challenging the roles of women in the changing culture of America during the 1910s. The term for film was more ambiguous as there were various terms used in the vernacular at the time, the most fruitful for my search were "photoplay" and "film". My time period of interest was dictated by the earliest contest found which bagan in 1911 and ended in 1918. This roughly coincides with the ending of World War I when newspaper contests changed their targeted audiences away from young women. Also, all of the contests that I examined for this study were terminated in 1918.

My research ultimately culminated in three distinctive, yet similar contests. These contests include: the Lyman H. Howe contests that ran in 1911 in different markets across the country; The Milwaukee Journal contest which ran in 1915 and the "Who Will Be Ruth?" contest which ran from 1915 to 1918 . These contests demonstrate how early fandom shaped and influenced popular culture, targeted the female reader and were pivotal in bringing peripheral cities into the core cultural practices of America. Film contests were important in the creation of a new leisure activity, which became part of a national mass market of entertainment creating one distinctive film culture. Mass 
marketing in the United States became intrinsically linked to leisure activities, and it became a powerful platform for corporations to advertise in order create a national market.

The discourse of the contests demonstrated the changing power dynamic of a distinct culture in America emerging through representations seen in films. The concept of discourse is integral to the study of power relations in society as Foucault described discourses as the tactical forces in the field of power relations. ${ }^{1}$ The study of discourse is important because documented language reveals how power is manifested in a given situation. They are not 'ideological representations' of class positions, but act as power shapers amongst the populace. Discourses are what change views, not merely overt acts of repression. According to Foucault discourses are therefore an "open and indefinite describable field of relationships" that construct our understanding of social reality. ${ }^{2}$ In Foucault's understanding, power is not concentrated in the state or in any institution such as "Hollywood" but is imminent in every social relation, produced in various centers or through a multitude of networks. ${ }^{3}$ In other words, power is a practice that produces structural relations through the creation of 'truth', or in my case a sense of authentic fandom. ${ }^{4}$ Consequently, discourses demonstrate how power operates in a society, and the discourses found in film pages in newspapers from 1911-1918 represent the changing power relations of women in the culture of America as a whole.

\footnotetext{
${ }^{1}$ Michel Foucault, The History of Sexuality: vol 1. (New York: Vintage Books, 1988-1990), 127.

${ }^{2}$ Michel Foucault, Madness and Civilization: A History of insanity in the Age of Reason, (New York: Vintage Books, 2004), 54.

${ }^{3}$ B. Jessop, "From Micro-powers to Governmentality: Foucault's work on statehood, state formation, statecraft and state power", Political Geography, 26, no. 1 (2007): 37.

${ }^{4}$ B Jessop,. Bringing the State Back in (Yet again): Reviews, Revisions, Rejections and Redirections. International Review of Sociology, 11, no. 2 (2001):40, 152.
} 
The three cases chosen show the progression of film contests in their discourses as part of a participatory culture engaging film fans. All three contests demonstrate a cultural shift in America, which was influenced, in part, by film culture. The Victorian era cultural values were stifling for many segments of the population, including women, and film helped to change these cultural values. The shift in the cultural practices of America through the leisure practices of filmgoing created an avenue for individuals to actively participate in this new culture, in part by partaking in movie contests. The three contests also demonstrate the gradual transformation of the process of participation of fandom. Initially the creation of "fans" was purely an advertising mechanism, as seen in the early Lyman $\mathrm{H}$. Howe contests, which were an inventive method of creating a temporary specific audience. These early contests can also be seen as staking out a legitimization of film within progressive policies; the contests presented films as a means to educate the public. Female readers were also targeted in the process of legitimization and popularization as seen in The Milwaukee Journal contest. Active participation as a means of changing cultural practices was the eventual result of early film contests. The "Who Will Be Ruth?" contests were a culmination of previous ventures and specifically targeted young women as an empowerment tool across an entire region, but also at a local scale. The newspaper contests demonstrate that the historical process of fandom was one of participation in the creation of cultural artifacts, which were the films themselves.

\section{Publics, Audiences and Fans}

In order to understand how contests were embedded within early participatory cultures it is important to understand how fan groups are created. The idea of a public can be utilized in understanding how fan communities are created. Michael Warner discussed 
in "Publics and Counterpublics" how a public is created. In Warner's estimation, publics can be created by both a shared event such as a theatrical event or through the communal experience of reading texts. ${ }^{5}$ Furthermore, Warner posits that a public must receive continual attention through reflexive circulation of discourse. In other words, it is not just one text that creates a public but a series. ${ }^{6}$ Warner states that "only when a previously existing discourse, periodical and sequential can be supposed, and a responding discourse be postulated, can a text address a public". ${ }^{7}$ Consequently newspaper texts help to disseminate ideas that create a public as a readership. While theatrical events such as filmgoing create a temporary public as an audience, it is also the circulation of discourse that creates a public over time and space. Thus, the movie going public was created out of their standard relationship to the texts of newspapers as much as repeated moviegoing.

The imagined communities of movie fandom, were created through the circulation of reading, visual and participatory discourses. Benedict Anderson utilized his theory of imagined communities to problematize the rise of nationalism, but the concept of imagined communities can be applied to other communities outside the nation-state. Anderson describes the creation of imagined communities as being largely based on the distribution of discourse in newspapers with graphic curiosities. Anderson states that newspapers were integral to the acceptance of nationalism and helped to create an imagined community:

Why this transformation should be so important for the birth of the imagined community of the nation can best be seen if we consider the basic structure of the two forms of imagining which first flowered in Europe in the eighteenth

\footnotetext{
${ }^{5}$ Michael Warner, "Publics and Counterpublics,",Public Culture 14,.no. 1 (2002): 61.

${ }^{6}$ ibid, 90.

${ }^{7}$ ibid, 61 .
} 
century: the novel and the newspaper. For these forms provided the technical means for 're-presenting' the kind of imagined community that is the nation. ${ }^{8}$

Newspapers became akin to religious texts, but in regional rather than universal terms, and created communities. Consequently, newspaper texts moreso than other practices helped to circulate discourses that created an imagined community for those other realms. The movie going public was then created out of their relationship to the texts of newspapers and the selective act of filmgoing. Fan groups can be defined as communities based on their interactions. Ethnologist Dorothy Noyes defines groups as a community who share the same social ideology, in other words a socially shared, imagined concept of the community:

The performance that constructs the community ideologically and emotionally also strengthens or changes the shape of networks by promoting interaction; it may even have the effect of breaking up a network by redrawing the boundaries within it. The community of the social imaginary coexists in a dialectical tension with the empirical world of day-to-day network contacts. The imagined community offers a focus for comparison and desire, and, at the same time, is itself subject to re-visionings in the light of everyday experience. This productive tension is the complex object we denote with the word group. ${ }^{9}$

Fan groups create community as a representative of both their social imagination and its empirical reality, which work together in a dialectic fashion constantly reinforcing each other. Fan communities develop from the interaction with texts and it is through this interaction that modern communities are developed.

As Benedict Anderson proposed, the circulation of discourse found in print media created the basis for modern communities, and it is through conversation on writing that discourse is spread. The idea that conversation led to film communities has been a notion

\footnotetext{
${ }^{8}$ Benedict Anderson, Imagined Communities: Reflections of Origin and Spread of Nationalism, (London: Verso, 1983), 16.

9 Dorothy Noyes, “Group”, The Journal of American Folklore 108, no. 432 (1995): 471.
} 
accepted in early cinema studies. Vachel Lindsay, who is often considered to be one of the earliest film scholars, stated that movie theatres should have changed their names to "conversational theatres" and moviegoers should be encouraged to engage in conversations regarding the films in order to create a community. ${ }^{10}$ As in Anderson's conception of imagined communities, print culture is a communal practice that shaped culture and it is through utilizing conversation through newspaper contests that early film exhibitors created fan communities.

Fandom is a concept that concerns how contemporary consumers of popular culture influence content and form social groups and personal identities around their appreciation. With the emergence of the Internet, fan groups have become more vocal and have garnered the attention of news reporters, academia and documentaries. For example, fandom has been explored in popular culture with documentaries such as Trekkies, Ringers: Lord of the Fans, Finding the Future: A Science Fiction Conversation, and Dune the Impossible. These documentaries investigate both the oddities of fandom and their power utilizing theories from academics such as Henry Jenkins, Janice Radway and John Fiske. Fan scholars focus on how fans themselves create popular culture. Jenkins particularly focuses on how intelligence communities on the Internet affect popular culture through "convergence". While contemporary fandom is an important avenue to study, the historical process of fandom can provide a glimpse of producers' and consumers' early attempts to engage with popular culture as enthusiastic fans. This study collects texts from 1911-1918 from newspapers and magazines in order to analyze the emergence of fan communities. It seeks to problematize the historical creation of movie

${ }^{10}$ Vachel Lindsay, The Art of the Moving Picture, (New York: Modern Library Publishing, 2000), 232. 
fandom and contradict the critical theory of a passive audience through feminist media scholarship and studies of fandom. My research utilizes discourse analysis in order to demonstrate the creation of movie fans as reading publics through their interaction with the print discourse of film and the creation of it as an event. This study will not be able to analyze every film discourse from this time period, but will be able to identify wider themes in the discourse through Internet database research and discourse analysis.

The participation in the creation of culture is in direct opposition to critical theorists who criticize film as a method of oppression arguing that it pacifies the masses and is not a true "art" form. Adorno and Horkheimer argue that the "culture industry" is an operation under capitalism to pacify the masses, and state that movies are not art as they are a business made into an ideology that justifies "the rubbish they produce". ${ }^{11}$ This argument ignores the active participation of fans in participatory cultures. Instead, I support the view that fans develop participatory cultures, which have a powerful relationship to the creation of content. Fan studies scholars have demonstrated that fans constitute networks, which are dynamic groups that shape culture outside the traditional forms of power relations due to their participatory practices through discourse. ${ }^{12}$

Fan studies scholars have disputed the notion that mass culture is a passive medium. Henry Jenkins is considered by many to be one of the founders of the field of fan studies and he has grappled with Adorno and Horkheimer's theory of a passive audience. Jenkins' work focused on the use of texts in creating communities. In Textual Poachers: Television Fans and Participatory Culture, Jenkins argued that it is through texts that fans are able to participate in the creation of culture, and that repeated consumption

\footnotetext{
${ }^{11}$ Theodor Adorno and Max Horkheimer. "The Culture Industry: Enlightenment as Mass Deception”, Dialectic of Enlightenment Trans. Edmund Jephcott, (Stanford: Stanford University Press, 2002) 242.

${ }^{12}$ Henry, Jenkins. Convergence Culture, (New York: New York University Press, 2006).
} 
actually is a method of creating participatory communities. Scholars who utilize Jenkins' model of inquiry, such as Nancy K. Balm, research how digital communities create participatory cultures. Balm describes in her seminal work Tune In, Log On: Soaps, Fandom and Online Community, how online soap opera fans create "a dynamic community of people with unique voices, distinctive traditions and enjoyable relationships." 13 The fan communities existed long before the Internet, and simply utilize the Internet as a mechanism to facilitate discussion and archiving. Many scholars influenced by Horkheimer and Adorno still rely on the passive audience model of inquiry. This is problematic in studying spectator relations with film, especially in terms of understanding the relations of subordinate groups within mass culture. Another Frankfort School scholar, Siegfried Kracaure, argued that modern entertainment practices were similar to Fordism and women's bodies are dehumanized to a signifier and "are transformed into 'mere building blocks, nothing more"'. ${ }^{14}$ Women, in Kracaure's estimation lack any power in film and his theory assumes that the female viewer is exposed to dehumanized signifiers who they identify with. Like many in the Frankfort school Kracaure assumes that women in particular are a passive audience and this theory continues to reverberate in film studies. Feminist scholars in particular have investigated not only how women are portrayed in cinema, but also how female audiences perceive and interact with these portrayals.

\section{Film Spectatorship and the Female Viewer}

Scholars have long debated the practices of spectators, and film studies often utilize a passive audience model in its conception of early movie fandom. According to Miriam

\footnotetext{
${ }^{13}$ Nancy K. Baym, Tune in, Log on: Soaps, Fandom, and Online Community, (Thousand Oaks, Calif.: Sage Publications, 2000), 2.

${ }^{14}$ Siegfried Kracauer, 'The mass ornament' (1927), New German Critique, no. 5 (Spring 1975):59.
} 
Hansen there was a shift of focus in film studies from "filmic objects and its structures" to the relations between films and viewers. ${ }^{15}$ While this shift concerning the studies of spectators is important, the spectator was deemed a passive subject in poststructuralist approaches and in feminist analysis focused on how cinema co-opts spectators' desires with dominant ideology. ${ }^{16}$

One of the most often cited works in feminist film theory is the theory of the male gaze by Laura Mulvey. Mulvey theorized that female spectators identified with the male characters on the screen as males were the active characters and women were only displayed in a passive role. This was symptomatic of the entire structure of Hollywood cinema which Mulvey deemed to be patriarchal at its core. Women were objectified in film for the male viewer and Mulvey identifies two methods of how Hollywood cinema produces pleasure. The first is the objectification of the image, and the second one the identification with it. Both of these mechanisms represent the mental desires of the male subject. Mulvey's theory of the male gaze was influenced by Freudian psychoanalysis. She theorized that the pleasure of narrative cinema for female spectators is the fetishistic pleasures of female objectification, which relate to the Freudian model of unconscious desires. ${ }^{17}$ Mulvey uses the notion of scopophilia to explain how pleasure is derived from subjecting someone to one's gaze. While her theory is an excellent analysis of the method of the Hollywood system, it lacks actual empirical evidence of how audiences interact with films. Mulvey's method has been criticized for lacking the ability to conceive how spectators react to material as, like Frankfort School scholars, it assumes a passive

\footnotetext{
${ }^{15}$ Miriam Hansen, Babel and Babylon: Spectatorship in American Silent Film (Cambridge, MA: Harvard University Press, 1991) 3.

${ }^{16}$ ibid.

${ }^{17}$ Jackie Stacey, Star Gazing: Hollywood Cinema and Female Spectatorship, (London: Routledge, 1994) 21, and Laura Mulvey, "Visual Pleasure and Narrative Cinema." Screen 16, no. 3 (Autumn 1975): 13.
} 
audience. As Jackie Stacey states in her critique, there is a "blanket dismissal of women in the cinema audience" and this has resulted in spectators' actual reactions to cinema being ignored. ${ }^{18}$ Mulvey's approach dismisses the viewer's ability to make meaning out of cultural artifacts, which has long been explored in feminist cultural studies.

Feminist cultural studies scholars have been influenced by the cultural studies notion that meaning does not only reside in texts and it is the relation between readers and texts that imbues meaning. Janice Radway was one of the first feminist scholars to grapple with female fans who consume patriarchal media. Radway conducted an extensive ethnographic analysis of romance novel fans and their participatory practices. Radway's work is very useful to problematize how subordinate groups, in Radway's case women, can influence content creation through their collective practices. Radway utilizes an ethnographic model in her research method, which while useful for contemporary studies, cannot be employed by my study. A feminist film historian who has utilized a historical perspective, Shelly Stamp, traced the development of the "movie struck girl" through the use of the serial film and other forms of early cinema. All of the feminist studies are useful; however, they lack the ability to conceptualize how fans shape mass culture on a large scale as a public.

Seeing the spectator as a passive recipient of a closed system negates the realities of the distinctive film public, which emerged with the introduction of film. Miriam Hansen proposes the major problem in film studies has been the lack of understanding of the public reception of cinema. ${ }^{19}$ Hansen proposes that early cinema constituted its own public sphere and she uses the Habermasian view of the public sphere to explore the

\footnotetext{
${ }^{18}$ ibid.

${ }^{19}$ ibid, 5.
} 
movie spectator. While the public sphere is an important notion to use in relation to cinema spectatorship, Warner's notion of individual publics is more useful when combined with Anderson's theory that texts create a public. The interactions that fan publics had with the circulation of discourse surrounding film helped transform cinema.

While motion pictures transformed from a cheap amusement to America's first mass medium during the first decade of the $20^{\text {th }}$ century, movie contests began to appear in American newspapers around 1910. The 1910s was a transformational time, which created a national industry, which shaped leisure practices from small to large communities across America. According to film historian Charlie Keil, the years between 1908 and 1917 were the most significant transformation in American film history. During the "transitional era," widespread changes affected film form, film genres, filmmaking practices, industry structure, exhibition sites, and audience demographics. 1910 was a revolutionary period in American society and as Ben Singer and Charlie Keil point out, this period helped shaped American identity including the "significance for a shared notion of Americanism-the movies". ${ }^{20}$

This transformation of movies can be characterized by progressive social practices, the creation of the movie palace and the movie star. The ideology of progressivism shaped many of the ideologies of American society, including moviegoing practices. The acceptance of progressivism culminated in the election of Woodrow Wilson in 1912; however, progressive tendencies were also apparent in the previous Taft and Roosevelt administrations. ${ }^{21}$ Progressivism is based on the notion of social progress and reform and there were initiatives introduced in this period to reform abusive labour practices and to

\footnotetext{
${ }^{20}$ Charlie Keil and Ben Singer, American Cinema of the 1910s:Themes and Variations (Newark, NJ: Rutgers University Press, 2009) 1.

${ }^{21}$ ibid, 4.
} 
increase standardized education practices. As Larry May points out, progressives were not opposed to the ruling order, as they were largely members of the upper classes, and they advocated for "healthy forms of leisure" for the masses. ${ }^{22}$. One report conducted by a progressive reformer stated that "film was five times more powerful than any other

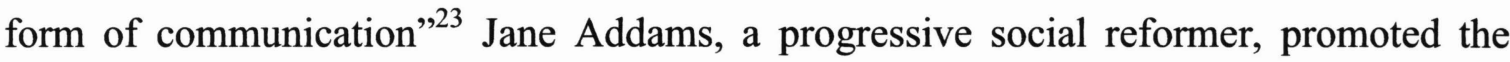
idea of film as a method of educating the urban poor and claimed the medium was already having positive effects in demonstrating that "man could be the master of his own fate. ${ }^{24}$ One of the largest groups to associate themselves with progressive politics were middle class women who were attracted to both the suffrage and temperance movements, culminating in a new idea of womanhood that developed under progressive ideologies.

According to Charlie Keil and Ben Signer, the idea of the new woman was introduced during the 1910s In the year 1910, seven million women were wage earners in America and only had voting rights in four western states. ${ }^{25}$ Women became a target for films, which embodied the modernist ideal of the progressive movement. 1910 was a landmark year in the production of docudramas of social reform and melodramatic reflections of the progressive movement. ${ }^{26}$ These new films centered on film heroines such as $A$ Child of the Ghetto, The Red Girl and A Child, Taming a Husband and Willful Peggy. Even genres like westerns, which are now male dominated, were targeted to the female audience and the "plucky cowgirl" became popular as demonstrated in the 1910 movie Ramona: A Story of the White Man's Injustice to the Indian staring Mary Pickford, who

\footnotetext{
${ }^{22}$ Lary May, Screening out The Past:The Birth of Mass Culture and the Motion Picture Industry, (Oxford: Oxford University Press, 1983), 45, 52.

${ }^{23}$ ibid 53.

${ }^{24}$ ibid.

${ }^{25}$ Charlie Keil and Ben Singer, American Cinema of the 1910s:Themes and Variations (Newark, NJ: Rutgers University Press, 2009), 5.

${ }^{26}$ ibid,33.
} 
was characteristically the emotional pillar, and clear star of the film. ${ }^{27}$. During this period in filmgoing, fan cultures also became more prevalent in newspapers who began to aggressively cover films and to specifically target the female audience.

\section{The Newspaper and Film Fandom}

The transformation of motion pictures occurred in part due to the circulation of discourse in newspapers. The motion picture ads of newspapers first began to appear within the theatrical releases and vaudeville pages at the turn of the century, but with the transition of movies to a mainstream pastime, these pages were also transformed. The "modernization" that occurred around 1913 was in part demonstrated by increased advertising. Advertising revenues doubled during this decade and one of the obvious beneficiaries of advertising was the mass circulation of newspapers and magazines. ${ }^{28}$ In the first decade of the new century, motion pictures did not have their own dedicated pages, and were often a part of the new "For the Interest of Women" section in newspapers. Soon theater times and locations were placed in newspapers, and also stories were being written to interest the general public in the act of movie going. As Paul Moore aptly points out, "journalism and promotion did not merely reflect and comment on the place of film in society. Newspapers fundamentally were agents themselves in reshaping the meaning and practice of going to the movies". ${ }^{29}$ In this sense, newspapers shaped the practices of movie going, and it is partly through the participation in movie contests by fans where this shaping of practices is apparent. Stories in the columns of newspapers

\footnotetext{
${ }^{27}$ Lary May, Screening out The Past: The Birth of Mass Culture and the Motion Picture Industry, (Oxford: Oxford University Press, 1983), 38.

${ }^{28}$ ibid,7.

${ }^{29}$ Paul Moore, Now Playing: Early Movie-going and the Regulation of Fun: Toronto 1906-1918. (Albany: SUNY Press. 2008), 14.
} 
became a very important advertisement for early motion pictures, and it is during this shift that movie contests were started to generate interest in the act of watching movies.

During the transitional era, when newspapers were coming to terms with the new media of film, movie contests illustrate an interesting dynamic in early fan discourses as they dealt with the relation of local issues to becoming part of the dominant national discourse. Many of the contests elicited fan participation in the creation of culture as they included local talent contests for women wanting to go to Hollywood. Early cinema developed a public by appealing to the local populations through these film contests. Local cinema contests were a method of self-recognition in the national industry of motion pictures. In the 1910 s, they represented a way that dominant American culture infiltrated peripheral rural areas. According to Ben Singer and Charlie Keil, the penetration of central ideas about movies came with new technologies and systems of transportation. ${ }^{30}$ It was through the traveling movie exhibitor that these central ideologies were disseminated and the national pastime of moviegoing became part of the local discourse.

The earliest movie contests located in the digital newspaper archives involve the showman Lyman H. Howe. Howe was one of the first film showmen, and became known as "America's foremost traveling film exhibitor". ${ }^{31}$ As a leading traveling exhibitor, he started his traveling exhibitions in 1883 and added motion pictures to his exhibit in 1896, which was the first year cinema was commercially available in North America. Howe was a prolific exhibitor, who developed his own projector, the animotoscope and his

\footnotetext{
${ }^{30}$ Charlie Keil and Ben Singer, American Cinema of the 1910s: Themes and Variations (Newark, NJ: Rutgers University Press, 2009) 2.

${ }^{31}$ Charles Musser, High Class Moving Pictures: Lyman H. Howe and the Forgotten Era of Traveling Exhibition, 1880-1920, (Princeton, NJ: Princeton Un1 versity Press, 1991) 1.
} 
shows were seen throughout North America until 1920. While Howe had less competition in his early days, by the start of second decade of the $20^{\text {th }}$ century Howe had to seek new methods to promote his films, because newspapers became less interested in publishing stories on his shows. Due to the emergence of permanent "nickelodeons" Howe became less special. ${ }^{32}$ One of Howe's inventive ways to promote his shows was to support contests in local newspapers. ${ }^{33}$

In 1911, one of his earliest contests was put on by The Pittsburg Press and asked readers to write why they enjoyed a certain film. The contest was in conjunction with the Lyman H Howe Festival, which was showcasing fifteen short moving pictures. ${ }^{34}$. The movie contest started on May 26,1911 and was announced in a box on the front page. In subsequent papers, the contest was explained in depth in the motion picture section. The contestants were asked to write a 50-word essay on which of the fifteen films would interest them. The first place winner received $\$ 50$, the second $\$ 25$ and the third $\$ 10$ and tickets to the festival would go to all three winners. Additionally, another 500 tickets would be mailed out to participants. The contest put emphasis on the words "your choice" and makes it clear that the audience is important. ${ }^{35}$ The films range from comedies, to dramas, to documentaries.

The contest was covered every day in the newspaper until the results were announced on June 11, 1911. When the results were revealed the newspaper published that the interest in the contest was "overwhelming" and the paper admitted to being unprepared for the high level of participation. This contest demonstrates that newspapers were a

\footnotetext{
${ }^{32}$ ibid, 219.

${ }^{33}$ ibid, 220.

34 "Hundreds of Prizes in Essay Contest", Pittsburg Press, June $11911, \mathrm{p} 4$.

35 “Enter The Press' Great Movie Contest”, Pittsburg Press, May 261911 p 1.
} 
catalyst in audience participation through the use of contests as early as 1911. In this contest early fans contributed to popular culture through their use of texts. The contest illustrates the interesting relationship that developed between advertising practices and progressive ideals. The Lyman H. Howe contests were clearly created as a form of advertising to help facilitate Howe's business model, but they also gave consumers a method of actively participating in their leisure activities through the use of texts. The contests also promoted the educational values of the progressive movement.

Many of the Lyman H. Howe contests dealt with educating the filmgoing public by the use of trivia contests. These contests dealt with answering trivia dealing with art and history. One of the contests that ran in several newspapers around the United States was the "Famous Building Contest". Readers were asked to identify pictures of the Seven Wonders of the World, and, if answered correctly, readers would win tickets to the Lyman H. Howe exhibition. This contest ran in newspapers in Pennsylvania, Michigan and Indiana in smaller markets. As with many of the later contests, it was announced to readers that the contest was unique, but it appears to be a prefabricated contest that was part of the promotions for the Lyman H. Howe exhibitions. The newspapers all remark on the popularity of the contest and the demographics of people who replied. In the Pennsylvania Wilkes-Barr Times, it is noted that every social class participated as evidenced by the different stationary, though they did mention that their readers were clearly all very educated in their responses. ${ }^{36}$ They also noted that female readers participated more fully in this competition. ${ }^{37}$

\footnotetext{
36 "Here Are The Names of the Winners in the Lyman Howe Contest", Wilkes Barre Times, October 2, 1913.

${ }^{37}$ ibid.
} 
The public that was created by the Lyman H. Howe contest was one that was based on the progressive notion of film being a healthy and educational leisure practice. A public is not based on an institution, and thus must cause renewed attention through visual entities. ${ }^{38}$ The public that was created in the Lyman H. Howe contests were not based on one institution, but rather were created out of a partnership between Howe, the newspaper and the exhibition venues. The publics were also based on the visual entities of the films. A public must also demand continual attention, and the filmgoing public was created through the continual attention placed on the practice through the Lyman $\mathrm{H}$. Howe contests. These contests made the contestants feel cultured and special by going to the show. The ability to answer trivia through the visual entity of the newspaper helped create a separate public for those participating.

The civilizing mechanism of the Lyman H. Howe contests continued and another contest was held in 1913 in Texas. The Fort-Worth Telegram ran a portrait trivia contest, advertising tickets to the Lyman H. Howe exhibition. Contestants needed to identify thirty-three portraits printed in the paper. The portraits included European royalty (Czarina of Russia), politicians (Woodrow Wilson) and newsmakers (J Pierpont Morgan). ${ }^{39}$ Women again were targeted by this contest and it is explicitly stated that far more women participated in the contest and that women paid closer attention to the visuals in a newspaper. ${ }^{40}$ Again this contest helped to create a sense that film was a legitimate leisure practice and film fans were part of a civilized community.

\footnotetext{
${ }^{38}$ Michael Warner, "Publics and Counterpublics," Public Culture 14. no. 1 (2002): 61.

39 "Picture Contest Shows Odd Things. Entrants Mistook Elbert Hubbard for Hetty Green the Winners Date", Fort Worth Star Telegram April 20, 1913.

40 "Picture Contest Shows Odd Things. Entrants Mistook Elbert Hubbard for Hetty Green the Winners Date", Fort Worth Star Telegram April 20, 1913.
} 
The early Lyman H. Howe contests established the conception of an imagined community as newspaper readers ("the fans") were integrated into broader communities through their participation in newspaper contests. As Benedict Anderson's notion of imagined community states: 'All communities larger than primordial villages of face-toface contact (and perhaps even these) are imagined'. ${ }^{41}$ Movie paper contests not only created imagined communities but also created dynamic fan cultures, which contradict the comments of critical theorists who state that films are mere reproductions and an opiate for proletariats in the capitalist system.

The participation in the creation of culture is in direct opposition to critical theorists who criticize film as a method of oppression, which pacifies the masses and is not a true "art" form. Adorno and Horkheimer argue that the "culture industry" is an operation under capitalism to pacify the masses. Adorno and Horkheimer state:

Movies and radio need no longer pretend to be art. The truth that they are just business is made into an ideology in order to justify the rubbish they deliberately produce. $^{42}$

This argument ignores the active participation of fans in imagined communities. Fan studies scholars have often invoked the idea of imagined communities to explain the nature of participatory cultures, and they have disputed the notion that mass culture is a passive medium. Henry Jenkins has grappled with both the theory of imagined communities and Adorno and Horkheimer's theory of a passive audience. Jenkins' work, like Benedict Anderson focused on the use of texts in creating communities. Jenkins argued that it is through texts that fans are able to participate in the creation of culture.

\footnotetext{
41 Benedict Anderson, Imagined Communities: Reflections of Origin and Spread of Nationalism, (London: Verso, 1983), 18.

42 Theodor Adorno and Max Horkheimer. "The Culture Industry: Enlightenment as Mass Deception", Dialectic of Enlightenment Trans. Edmund Jephcott. )Stanford: Stanford University Press, 2002) 242.
} 
Jenkins particularly contradicts Adorno's conception of how cultural texts have disintegrated with overconsumption and that consumption transforms sacred artifacts into cultural goods. ${ }^{43}$ Jenkins proposes that repeated consumption actually is a method of creating participatory communities. Again the notion of consumption as a transformational process is also present in Anderson's work as imagined communities can only be conceived through the consumption of texts.

The consumption of texts through the use of contests has a historical precedent in newspapers. The Lyman H. Howe contests were a modern incarnation of the use of serials to engage consumers in literature. Serials began to appear in the 1700 s as a means for publishers to spread the cost of production and to have subscribers continually purchasing new materials. ${ }^{44}$ The first serials were made available in periodicals and then magazines. Two popular examples of the early serial trends were Town and Country Magazine, which ran serials from 1769-96, and Lady's Magazine, which ran serials from $1770-1837 .{ }^{45}$ From the 1730 s onwards, newspapers also published serials reflecting the changing practices of the reading public. For example, the novel replaced poetry as the popular form of reading during this period and newspapers started to print serials of popular novels. Dickens was actually made popular through the serial format and his novels have the episodic arrangement of their original publication method. Popular newspapers and magazines needed to attract the female readership and they did this through the use of serials and stories of "plucky young women", and Ben Singer notes

\footnotetext{
${ }^{43}$ Henry Jenkins, Textual Poachers: Television Fans \& Participatory Culture. (New York: Routledge, 1992). 51.

${ }^{44}$ Graham Law, Serializing Fiction in the Victorian Press (Hampshire, Palgrave, 2000). 3.

${ }^{45}$ ibid, 4.
} 
these stories appeared as early as the $1890 \mathrm{~s} .{ }^{46}$ Much like film contests, the popularization of serials were also often paired with contests.

\section{Women's Serial Film Reading}

The film serial was developed in the early teens of the $20^{\text {th }}$ century and focused on strong female heroines performing great feats of strength and ingenuity against some form of evil. While the genre is paradoxical with its portrayal of female power accompanied by sadistic scenes of female victimization, Ben Signer states, "serial films go out of their way to construct a textual arena for fantasies appealing particularly to female spectators". ${ }^{47}$ As Richard Abel, Ben Singer and Shelly Stamp have noted the serial was the film industry's method of addressing the growing female audience and demanded the active participation of this audience.

The motion picture industry cultivated the female audience by feverishly promoting motion pictures to women. Shelly Stamp points out it was during the 1910s that women were most openly and aggressively solicited and young female movie fans became the staple of many exhibitors' businesses with advertising campaigns and promotions to attract them and stories geared towards their interests. ${ }^{48}$ In many motion picture contests, newspapers assisted in the promotion of the female audience. Local film contests created a sense of agency and self-recognition for the largely female audiences. In these contests women were not only encouraged to participate in motion pictures but also to create content. Movie theatres often ran promotions to appeal to women and the genre of the

\footnotetext{
${ }^{46}$ Ben Singer, Melodrama and Modernity: Early Sensational Cinema and Its Contexts (New York: Columbia University Press, 2001) 246.

${ }^{47}$ ibid, 222.

${ }^{48}$ Shelly Stamp, Movie-struck girls: women and motion picture culture after the nickelodeon, (Princeton, NJ: Princeton University Press, 2000), 2.
} 
serial was created to cater to female audiences. ${ }^{49}$ The serial is distinctive in cinema history because it encourages intertextual viewing practices and challenged traditional gender roles. ${ }^{50}$ Newspapers assisted in the promotion of the female audience in their motion picture contests. In these contests women were not only encouraged to participate in motion pictures but also to create content.

By 1915 , there were various contests that encouraged participation in the creation of content for motion pictures. Richard Abel demonstrates that contests became part of the serial genre as newspaper tie-ins became the norm. In 1912, the What Happened to Mary? contest had each episode's story published in Ladies World.$^{51}$ Ladies World actually credited the What Happened to Mary? contest for increasing circulation by 100,000 subscribers. ${ }^{52}$ As a tie-in to the serial, Ladies World ran contests to actively engage the readership. Each month, the serial posed the question "What will happen to Mary next?" offering a $\$ 100$ prize to the reader who most successfully answered the question. ${ }^{53}$ By the fifth month of the contest, there were almost 10,000 responses and a couple of winning essays actually became the plot of the next installment of the film. ${ }^{54}$ As Nan Enstad theorized, these contests were a mechanism to train the audience as "fans". 55

After the success of the What Happened to Mary? series, serials began to run in newspapers across America. In 1914, the biggest serial contest started with a partnership

\footnotetext{
${ }^{49}$ ibid.

${ }^{50}$ ibid.

${ }^{51}$ Richard Abel, Americanizing the Movies and "Movie-Mad" Audiences, 1910-1914 (Los Angeles, University of California Press, 2006), 195.

${ }^{52}$ Nan Estad, Dressed for Adventure: Working Women and Silent Movie Serials in the 1910s, Feminist Studies, Vol. 21, No. 1 (1995): 73

${ }^{53}$ ibid.

54 ibid.

${ }^{55}$ ibid.
} 
between Pathé American and Hearst Newspapers, The Perils of Pauline. This serial utilized trivia contests, not unlike the Lyman H. Howe contests. The trivia contests asked audiences to solve mysteries placed in each episode with a prize of $\$ 1,000 .^{56}$ With the aggressive marketing campaign, The Perils of Pauline became one of the most popular films ever and broke all records for bookings and patron pulling power. ${ }^{57}$

With the popularity of national contests like "What Happened to Mary?" and The Perils of Pauline, local newspapers began to also engage female fans of serials. The Milwaukee Journal embarked on a contest in April 1915 asking readers to write a motion picture script. Readers were asked to construct a story for a motion picture that would be shot in partnership between The Milwaukee Journal and the Strand Theatre. The guidelines were that the story must not exceed seven hundred and fifty words and be typewritten, and the winner would receive a $\$ 50$ gold watch. The contest was named the "Made in Milwaukee Picture Play" and named only two caveats: the location of the story must be able to be shot in "out-doors Milwaukee" and the plot must deal with the present day. ${ }^{58}$ The paper promised that the photoplay would showcase Milwaukee and give Milwaukeeans opportunities. ${ }^{59}$ The inclusion of local culture helped to both popularize and legitimize filmgoing as a leisure pastime.

The "Made in Milwaukee Picture Play" engaged local women in the practices of film and the contest had space in the newspaper each day. The winner was announced on Sunday, April 25, 1915 in the Sunday picture pages and a further contest was announced

\footnotetext{
${ }^{56}$ Richard Able, Americanizing the Movies and "Movie-Mad" Audiences, 1910-1914 ( Los Angeles, University of California Press, 2006) 208.

${ }^{57}$ ibid.

58 "Only One More Week Remains For Motion Picture Writers To Send Stories For Film", Milwaukee Journal April 18, 1915.

${ }^{59}$ Mary Robinson, "Moving Picture Actress': Life in Made in Milwaukee Production is Strenuous" Milwaukee Journal, May 9, 1915, p 5.
} 
to cast the motion picture. The story chosen was “Jozie's Jitney Duke", about a young woman who dumps her loving boyfriend with dreams of becoming a Duchess after she received a proposal from an unscrupulous Duke. The villain Duke is actually already married and isn't actually even a Duke. Eventually all is revealed and Jozie marries her dutiful boyfriend after escaping the evil Duke's clutches. While this story is not as empowering as many of the serial films, Jozie is still able to have a happy ending after being "spoiled" by the duke and is able to save herself from a dangerous situation.

The Milwaukee Journal continually engaged their "public" by publishing a story synopsis and a thorough explanation of each scene that would be shot. ${ }^{60}$ Journal reporter Mary Robinson wrote a continuous column throughout the shooting of the photoplay with humorous anecdotes surrounding the filming. ${ }^{61}$. Mary Robinson detailed how readers descended on the Strand Theatre to be chosen for the parts in the film. Interestingly, Robinson noted that the vast amount of people who participated attempted to lie about their age and marital status in order to be considered. ${ }^{62}$ The public that was addressed in this contest were female serial fans, who wanted to create their own serial, and were inspired to do so by the Milwaukee Journal. An integral feature of how the social is created, according to Warner, is reflexive circulation of discourse; it is not just one text that creates a public. ${ }^{63}$ As previously mentioned, Warner theorized that "only when a previously existing discourse can be supposed, and a responding discourse be postulated,

\footnotetext{
${ }^{60}$ Mary Robinson, "Finished Scenario Show 'Movie' Fans Big Step in Film Making and Provides Ambitions Photoplay Writers with Model”, Milwaukee Journal, May 9, 1915, p. 24.

${ }^{61}$ Including one where she writes almost an entire article on a dog in the film. See Mary Robinson, "Poodle Best Actor in Film", Milwaukee Journal, May 10, 1915 p 9.

${ }^{62}$ Mary Robinson “Adventures of 'Movie' Told in Detail”, Milwaukee Journal , May 16, 1915, p 22

${ }^{63}$ ibid, 90.
} 


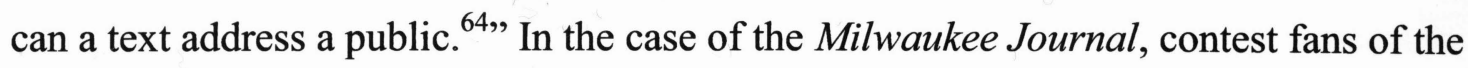
existing serial model were able to create their own texts in response to the film. The paper also continued circulating the discourse surrounding the film by covering the story every day.

Benedict Anderson proposes that the narrative form found in novels and newspapers replicates how the nation is constructed. Imagined communities replicate the nation based on the simultaneous process of the circulation of texts. Anderson states that circulation of newspapers is analogous to the idea of the nation because the action of reading newspapers is an anonymous simultaneous activity. Anderson writes, “An American will never meet, or even know the names of more than a handful of his 240,000 -odd Americans. He has no idea of what they are up to at any one time. But he has complete confidence in their steady, anonymous, simultaneous activity". ${ }^{65}$ This anonymous simultaneity was present in movie contests like the Milwaukee Journal contest, which demonstrated the use of narrative to create community through simultaneous participation by the public in the process of filmmaking. This contest engaged the community, who followed it on a daily basis to create their own script. The simultaneous participation by the public in newspaper contests created engagement in the private sphere of the actions of the public sphere. The readers of the Milwaukee Journal did not know each other, but were able to come together based on the story of communal filmmaking. Local film contests created identity based on participating in the national pastime of filmgoing, essentially creating the very content they consumed.

\footnotetext{
${ }^{64}$ ibid, 61.

${ }^{65}$ Benedict Anderson, Imagined Communities: Reflections of Origin and Spread of Nationalism, (London: Verso, 1983), 25.
} 
Movie contests contributed to the creation of culture, and contests urged readers to get involved in the process of filmmaking. There were early contests across America for people to compete to write scripts or to be in films. These early interactions with creation of content are an early incarnation of the creation of popular culture. As defined by John Fiske, popular culture is based on its connection to subordinate groups. Popular culture, while originally outside the dominant culture, is appropriated - thus, making popular culture inherently contradictory. Fiske also defined the term excorporation as "the process by which the subordinate make their own culture out of the resources and commodities provided by the dominant system" ${ }^{66}$ Fiske's understanding of popular culture is important to the early movie contests because many of them appealed to subordinate classes and incorporated their ideals. Women were specifically targeted by these contests and they created a sense of agency for female readers. These female readers helped to create the popular fan cultures surrounding motion pictures.

Local film contests created a sense of agency and self-recognition for the largely female audiences. Anderson noted that the development of nationalism was based on the inclusion of subordinate groups such as women, with the availability and accessibility of discourse that came with print capitalism and the reformation. Anderson proposed that the inclusion of women through the acceptance of the use of vernacular in print mobilized women for politico-religious purposes, and not only changed religion but Europe as a whole. ${ }^{67}$ Film provided a similar path for inclusion as women appearing in movie audiences gave motion pictures the cultural capital to be accepted. According to Eunice Ball, as quoted by Shelly Stamp, who wrote in 1913 that the presence of wives, mothers,

\footnotetext{
${ }_{67}^{66}$ John Fiske, Understanding Popular Culture, (Boston: Unwin Hyman, 1989) 49.

${ }^{67}$ Benedict Anderson, Imagined Communities: Reflections of Origin and Spread of Nationalism, (London: Verso, 1983), 25
} 
sisters and daughters changed movies from a lower class pastime to a standard amusement. ${ }^{68}$ Female spectators were important in popularizing the motion picture industry. Miriam Hanson demonstrates in her work that women have always made up a large majority of the film audience as early as the Corbett-Fitzsimmon's fight in 1897. Cinemagoing transformed the pleasure seeking habits of women at the turn of the century as Kathy Peiss, Lauren Rabinovitz, Shelly Stamp and many others have demonstrated.

\section{The Man Haters: Networks of Female Fans}

The Women's movement in the late 1800 s and early $20^{\text {th }}$ century was organized and vocal in the pursuit of voting rights for women. The demographics of the suffragette movement were largely upper and middle class women with disposable incomes that would allow them to consume products. The suffragette movement became popularized and newspapers became focused on the changing roles for women to appeal to the female consumer. As Ben Singer states, news stories became focused on the idea of the new woman, and this can be seen as early as the late 1800 s. One of the terms that became associated with the "new woman" was "man hater", with stories in newspapers reflecting male anxieties of female political groups rejecting men entirely. The earliest mention in the digital archives of the term "man haters" is in an article from the Janesville Gazette published June 8,1871 . This article is a reprint from the Washington Star and presumably was reprinted in other smaller markets. The article reports that magazines in London have recognized that "the odd social phenomenon of the present day is the class of women who are professional despisers of men" ${ }^{69}$ The article goes on to state that there are three different types of women who become "man haters"; those who have been badly treated

\footnotetext{
${ }^{68}$ Shelly Stamp, Movie-struck girls: women and motion picture culture after the nickelodeon, (Princeton, NJ: Princeton University Press, 2000) 1.

69 "Man-Haters", Janesville Gazette, June 8, 1871, p. 1.
} 
by men, those who are greedy and indifferent to home life, and those who hate men based on perversion. ${ }^{70}$ The article is particularly concerned that man haters have constructed men into a "sexual enemy", and decried what may occur if this phenomenon continues. Stories about groups of women creating "man hating" groups peaked in the 1890s, and the Olean Democrat published an editorial on the "man hating craze that was written about across the nation". The Olean article insightfully stated that it is a passing phase caused by the changing roles of women. ${ }^{71}$

There continued to be reports in newspapers regarding the new trend of man hating into the new century. In 1908, there were various stories regarding "man hating" clubs. In the Mills County Tribune published in Glenwood, Iowa, there was a story printed from New York about a club of man hating women in Williamsburg. The article stated that members had to pledge to avoid all interactions with men outside of business relations and women had to provide all correspondence with men for inspection. ${ }^{72}$ The "man hating" phenomenon eventually culminated with fears of entire communities of women rejecting men, and there were various stories on the Belton's Woman's Commonwealth in 1908. The Commonwealth, a Protestant commune, was originally founded in Texas in the late 1860 s on the basis of female celibacy and communal living, and later relocated to Maryland. The community consisted of nineteen women and children, but despite the dwindling numbers newspapers routinely reported on the community.

A fascination with "man hating" groups revolved around the idea of women in these groups succumbing to love. On April 29, 1908 in the Pittsburg Press a story on the

\footnotetext{
${ }^{70}$ ibid.

71 "Few Women Man Haters", Olean Democrat, Tuesday, July 05, 1892, p. 7.

72 "Old Maids of Town Cause Scandal By Suggesting Prize for Best Proposal", Mills County Tribune, Tuesday, January 07, 1908, p.9.
} 
Belton's Woman's Commonwealth was reported in the "For Interest of Women" section of the paper. The story chronicled Adah Pratt, who was born into the community and married the first man she ever met despite her indoctrination into "man hating". Another article on the same story appeared in the Trenton Evening Times, which reported on June 2, 1908 about the community. The article states the commune recently suffered a setback when Adah Pratt was “stolen away" by a hotel clerk from Philadelphia. Newspaper stories of man hating women falling in love were codified into Clyde Fitch's play, Girls, which first was shown in New York City at Daly's Theatre. A story ran in the New York Times on April 2, 1908, which recounted that the Daly Theatre ran an April Fools day promotion to lure "man haters" into the theatre to see the play. ${ }^{73}$ Daly's theatre attracted female viewers by holding a "man haters" matinee and sending free tickets to hundreds of women who packed the theatre. The Tribune in La Crosse, Wisconsin also had a story on Girls coming from New York and was played at the La Crosse Theatre in Wisconsin. This article described that the plot revolved around a group of man haters, and the leader of the group falls in love with a man. ${ }^{74}$

Love stories drove part of the man-hating craze, and in 1913 a serial fiction story ran in various small town local newspapers regarding an amusement park in a community called Lakeside, which was identified as the Coney Island of the West. In the story the amusement park offered a promotion for free tickets to women who self identified as man haters. The plot thickens when the incentive was deemed such a success that the amusement park ran a man haters week. The storyline is one of romance between the

\footnotetext{
73 "Matinees For Sex Haters", New York Times, April 2, 1908, p. 7.

74 "Girls Comes Next Wednesday", La Crosse Tribune, November 7, 1908, p. 9

The play Girls was later adapted into a Hollywood film in 1919 staring Marguerite Clark, and played across North America. More details can be found in "Man Hater Club That Lost Charter", Winnipeg Free Press, Tuesday, August 19, 1919, p. 6.
} 
head of the amusement park and a confirmed man hater. They fall in love over an incubator baby that they found in one of the exhibitions and live happily ever after. The love stories regarding man hating women grapple with the anxiety of women's new role in society and how men and women can come to terms with these changing roles. The man hating craze paired the serial genre with participatory cultures surrounding film contests.

The serial contest that exemplifies the inclusion of women in the creation of a participatory community is the "Who Will Be Ruth?" contest, which ran from 1915-1918. The "Who Will Be Ruth?" resulted in the same movie, The Man Haters shot in each individual city that the contest ran. Each contest created a space for active participation in the filmmaking process for female fans. The plot of the movie lends itself to the man hating craze as it is about a group of women who reject traditional gender roles. Just as in Clyde Fitch's play Girls, Ruth is the leader of a group of "man haters" and eventually marries her love interest Henry. One striking contrast between the Man Haters and other "man hating" stories is that Ruth reiterates her hatred for all men except Henry at the end of the film, creating a sense of acceptance of "man hating". The Man Haters and its surrounding contest both capitalized and normalized the idea of the "new women", and created a space for female fans to influence the creation of cultural artifacts.

The "Who Will Be Ruth?" contest started in Ohio in 1915. Basil McHenry, of Akron Ohio, a former vaudeville and circus performer, branched out into the movie making business, and not unlike Lyman $\mathrm{H}$. Howe, recognized the adverting advantages of film contests. Basil McHenry developed a formula of working with local theatres and newspapers in order to create a film contest which appealed to female fans. The earliest 
"Who Will Be Ruth?" contest was in Lima, Ohio starting May 12, 1915. The Lima Daily

News prominently promoted the contest and had banners on the front-page everyday promoting it and updating the public on the progress of the contest. The textual analysis of the Lima contest demonstrates that the contest was geared towards women, as only women were involved involved in the contest, as the producers chose the male roles. ${ }^{75}$ The stories in the newspaper discussed the popularity of the contest but never discussed the title of the movie or the scenario until the winners were chosen, nor was it ever revealed that the contest had been held in other cities. The contest proved popular in Lima and ended May 26, 1915 awarding Louise Mattenson, with thousands of votes, the role of Ruth. ${ }^{76}$

Basil McHenry continued traveling the country with the contest and he generally stayed in the Midwestern part of the United States. While the contest was generally run in the middle of the country McHenry did travel south to West Virginia and Kentucky and north to New York. ${ }^{77}$ It is very likely that the cities chosen were due to train routes as the Midwest was a hub for train lines. A map of train routs from 1918 demonstrates that the all the cities were in the epicenter of several train lines (See Appendix A and B for a map of the contests found in this research project and Map of train lines from 1918). The locations of the contests were all in smaller cities and towns, and could all be deemed

\footnotetext{
${ }^{75}$ ibid.

76 “Troubles Even Occur In Life of Movie Queen”, Lima Daily News, May 30, 1915, p. 8.

${ }^{77}$ The contests continued onto Cedar Rapids in early July 1915 in the Cedar Rapids Republic, in Mansfield Ohio in late July 1915, in The Mansfield News, in Newark Ohio in The Newark Daily Advocate in September 1915, in Muncie, Indiana in the Muncie Evening Press and Kokomo, Indiana in The Kokomo Tribune in October 1915, both the Journal Tribune of Logansport, Indiana and Sunday Vindicator of Youngstown Ohio in November 1915, in the Bluefield Daily Telegraph Bluefield, West Virginia in February, 1916, , in the Hamilton Journal in April 1916 in Hamilton Ohio, The Piqua Daily Press in Piqua, Ohio in May 1916, Derrick, Pennsylvania in June 1916, in Hagerstown Maryland in The Morning Herald in September 1916, in the Oil City Derrick, The Dunkirk Observer of Dunkirk, New York in early June 1916, the Lexington Leader in Lexington Kentucky in November 1916, in Altoona, Pennsylvania in the Altoona Mirror in March 1918. All the contests, like the one in Lima were geared towards the female population. (See Appendix: A for a map of the contests found in this research project).
} 
peripheral based on their size. Movie contests were a method of creating a sense of shared American film practice for smaller communities.

The ability to utilize film contests as a mechanism for normalizing moviegoing, can be demonstrated in the popularity of the contests. The popularity of the contests varied, though it appears they were all very popular for the size of their cities. The larger contests had tens of thousands of votes. Cedar Rapids had over 50,000 votes and Kathryn Barker won with 15,205 votes. ${ }^{78}$ In Mansfield, Georgia Edwards won the role of Ruth with 52,540 votes. The largest contest was in Youngstown where the paper stated they had to increase demand by 60,000 papers due to the contest and Florence Ross won with 96,490 votes. ${ }^{79}$ The smaller competitions still had thousands of votes, in The Dunkirk Observer Sadie Mulcahy won with 5,810 votes and there were 25,000 votes in total. ${ }^{80}$ Muncie, Ohio also had a smaller number of votes as Dora Grim won with 4,434 votes $^{81}$. Even in the smaller competitions like Muncie, it was stated that girls would follow Press carriers around and enlist the help of local newsboys to collect as many coupons as possible. ${ }^{82}$ The popularity of the voting process is important because these competitions not only created a space for women to contribute to the creation of culture, but also gave them agency in a time before political voting rights were universal.

While these contests ran in different cities the formula was similar, as they all appealed to female readers. The opening articles of almost all of the contests had the same first lines. In Lima, Cedar Rapids, Mansfield, Logansport, and Youngtown all open

\footnotetext{
78 "Kathryn Barker Chosen For Ruth", Cedar Rapids Republican, July 25, 1915, p 2.

79 "Miss Florence Ross Declared Winner of Movie Contest", The Sunday Vindicator, November 21, 1915. p 3 .

80 "Miss Sadie Mulcahy Ruth in Photo-Play", Dunkirk Observer, July 14 1916, 4.

${ }^{81}$ Nancy Turner, Having Fun With It: The Man Haters Project (Muncie, Indiana: Ball State University, 2007) 7.

${ }^{82}$ ibid, 6.
} 
up the contest with the lines "Who will be Ruth? (name of city) girls and women ask yourself this question and herewith become acquainted with (name of paper) motion picture contest." The contests also had a similar vernacular for the stories that ran on the second day of the contest. These stories all stated that their "telephones have been answering hundreds of questions" about the contests and gave women tips for successfully competing in the contest such as "line up all your friends to vote for you". It appears that the McHenry Film Company may have sent out press releases for the papers to follow, as all the coupons and rules also are the same for every contest. All of the contests state that the girl must be over the age of sixteen, a local of the city and an amateur who has never appeared in a film.

The contests would only appear in one paper of record in the town and the other newspapers would not advertise the contest. In the case of Kentucky, the Lexington Herald is in the online archive, but not the Lexington Leader. The Herald's only reference was an advertisement that was put out by the Strand movie theatre, which states that The Man Haters, shot locally, would be shown at the theater. The director is also the same for the contests with the earlier director named Bannage and the subsequent director named Conklin. ${ }^{83}$ This also happened in Altoona, the last contest found, as the only mention of the contest available in the archive is in the Altoona Mirror, which had an ad regarding a local photoplay called the Manhaters. The ad stated that the cast was selected by a contest, and played at the Wilmer \& Vincents Orpheum in March 1918. There was also another contest that was left out of the online archive, but appeared in an ad in 1929 in The Kokomo Tribune in Kokomo, Indiana. The ad stated that The Man Haters was the

\footnotetext{
${ }^{83}$ It is interesting to note that the Ball State investigation seemed to think that the company picked local directors and though the Bannage mentioned in the papers many have been a local painter, but as Bannage is mentioned in other competitions he clearly worked for the McHenry company.
} 
"best home talent picture ever made in Kokomo" and that the film was shot in October 1915.

There were differences in some of the contests. In Muncie, Indiana the contest in the town was studied by Ball State University, and it was discovered that one actress in the motion picture was fifteen, even though the newspaper claimed to only allow girls over sixteen to enter. ${ }^{84}$ The contest in Cedar Rapids appears to be the most unique contest. The opening article cannot be found in the Internet archives, but the rules and format of subsequent articles resembled the other contests; however, the production company is said to be a "Midwestern company from Chicago" and a subsequent article calls it the "Universal Camera Company". ${ }^{85}$ This suggests that either other production companies were running the same contest, or McHenry changed its name for this contest. The Dunkirk Observer was a later contest and it also did not have the same opening script that was found in the other contests, but it does clearly state the McHenry Film Company is behind the film. The Dunkirk example suggests that McHenry may have changed press releases as the competition went on.

The storylines of the movies also varied. The only available copy of the Man Haters movie is available through the Ball State University collection. The exact plot of the film is not discussed in any of the contests, but there are certain discussions of important scenes that differ from each other. As in many serial movies, the heroine is in peril and in various contests Ruth is rescued from danger. The Youngstown version has a scene where Ruth is rescued from a frigid river by her future husband. ${ }^{86}$ The Dunkirk Observer,

\footnotetext{
${ }^{84}$ Nancy Turner, Having Fun With It: The Man Haters Project (Muncie, Indiana: Ball State University, 2007) 14.

85 "Kathryn Barker Chosen For Ruth", Cedar Rapids Republican, July 25, 1915, p 2.

${ }^{86}$ "Vindy Movie is Produced on Schedule", The Sunday Vindicator, November 28, 1915, p 2.
} 
the Kokomo Tribune and the Morning Herald mention a scene where Ruth is rescued from a burning building. ${ }^{87}$ In the Morning Herald there were two front page articles on the fire scene in the film and the story stated that both Ruth and Henry were stuck in a burning building and they were rescued by actual members of the local fire department. The Kokomo Tribune, in its ad also mentions that local firefighters took part in the film. It appears the difference in the scripts was meant to showcase local monuments and groups, creating a sense of the local in the national pastime of films.

The "Who Will Be Ruth?" competitions created a space for women to create their own serial movie. As previously stated, the serial is distinctive in cinema history because it encourages intertextual viewing practices, and challenged traditional gender roles. ${ }^{88}$ The "Who Will Be Ruth?" contests embody the serial as the contest utilized both newspapers and motion pictures to create entertainment for the female audience, consequently causing the viewing practices to be intertextual. The plot of the movie also lends itself to the serial genre as it is about a group of women who reject traditional gender roles. The Man Haters and the surrounding contest helped to involve the female audience in a genre that was uniquely feminine, and assisted in the creation of a dynamic female fan culture.

\section{Conclusions}

The circulation of movie contests in newspapers from 1911-1918 created a movie public, and this public became creators of a new popular culture. Motion pictures became the first American mass media, and female fans popularized the medium. The genesis of movie contests was due to the need to create publicity for a burgeoning media and to help

\footnotetext{
${ }^{87}$ “All Dunkirk Play at Empire Today”, Dunkirk Observer, July 31, 1916, p. 1.

${ }^{88}$ Shelly Stamp, Movie-struck girls: women and motion picture culture after the nickelodeon, (Princeton, NJ: Princeton University Press, 2000), 102.
} 
popularize it. Lyman H. Howe realized the potential of newspapers in the popularization of motion pictures, and created contests in order to create a loyal public for his exhibitions. The Milwaukee Journal contest and the "Who Will Be Ruth?" contest capitalized on the popularity of serials and helped fans form a collective identity through the circulation of texts. Motion pictures became the first American mass media, and female fans popularized the medium due to the collective practices of communities through a cyclical relationship with newspapers.

While dynamic fan communities were created, the story of Ruth Purcell found in the Times Democrat of Muskogee, Oklahoma demonstrates the complexities of female fans who participated in movie contests. Women like Ruth Purcell were given agency in these contests but were also criticized by the very newspapers promoting the contests. Ruth Purcell was forced into the role of the reluctant movie star in order to not be portrayed as the "frivolous" and "silly" woman, which became the norm in later contests. By the end of the 1910s, the portrayal of female fans changed in mass culture, and just as newspapers celebrated early female fans they began to demonize them.

The agency for women that was created in the 1910s was later regulated by American society with the decline of strong female protagonists in the Hollywood era, as both Shelly Stamp and Miriam Hansen have pointed out in their work. Hansen theorizes that spectator reception of these films targeted for female consumption gave rise to a female subculture, which was threatening as "it challenged the sexual economy of the relations of representation and reception and temporarily derailed the consumerist appropriation of female desire into the dynamics of public life" ${ }^{89}$ This subculture was short lived as

\footnotetext{
${ }^{89}$ Miriam Hansen, Babel and Babylon: Spectatorship in American Silent Film (Cambridge, MA: Harvard University Press, 1991), 34.
} 
regulatory mechanisms came into place. In 1915 there was a shift in cinema in America when the Supreme Court handed down the Mutual Film Corporation v. Industrial Commission of Ohio decision which denied motion pictures the constitutional protection of freedom of speech by refusing them a "public status" ".90 The decision was the culmination of efforts on the local and state levels, to establish control of motion pictures- and Hanson suggests this was because the dominant forces discerned in film the formation of an alternative public sphere". ${ }^{91}$

Subsequently, magazines and newspapers also began to regulate female fandom by criticizing the behavior of fans. Shelly Stamp discusses the troubled relationship that women had with film in the media that was characterized by "the movie struck girl", the fan who confused the love of cinema with the desire to appear on screen herself. ${ }^{92}$ Magazines and newspapers began to portray women as having a "crazy" relationship to the screen that needed to be regulated. The story of Ruth Purcell fits into this pattern as she was celebrated in the Times Democrat of Muskogee, Oklahoma for not becoming a "movie struck girl". There was a fear of the autonomy or "man hating" that was created by contests like "Who Will Be Ruth?." and there seems to be a pattern of acceptance of female fans in print media followed by ridicule when female fans become disengaged with the dominant public sphere.

Participatory groups were formed through the film competitions, as the creation of content is important for popularization. This concept contradicts critical perspectives on mass media and demonstrated media consumption is not passive. In Anderson's conception national identity was only able to form when subordinate groups were able to

\footnotetext{
${ }^{90}$ ibid.

${ }^{91}$ ibid.

${ }^{92}$ ibid.
} 
become part of collective practices. Later motion picture competitions recognized that creation of content is important for popularization and created opportunities for women to participate in the creation of content for motion pictures. The "Who Will Be Ruth?" competition exemplifies the process of utilizing popular culture that is later co-opted by mass culture. This contest recognized the importance of supporting female agency in order to popularize the medium of motion pictures. Both the genre and the contest surrounding the Man Hater motion pictures helped to develop a popular culture that supported female agency through female fandom. While regulations were later put in place the "Who Will Be Ruth?" contest exemplifies a historical period where female agency was celebrated in film, which created a dynamic fan community. 
Appendix A:

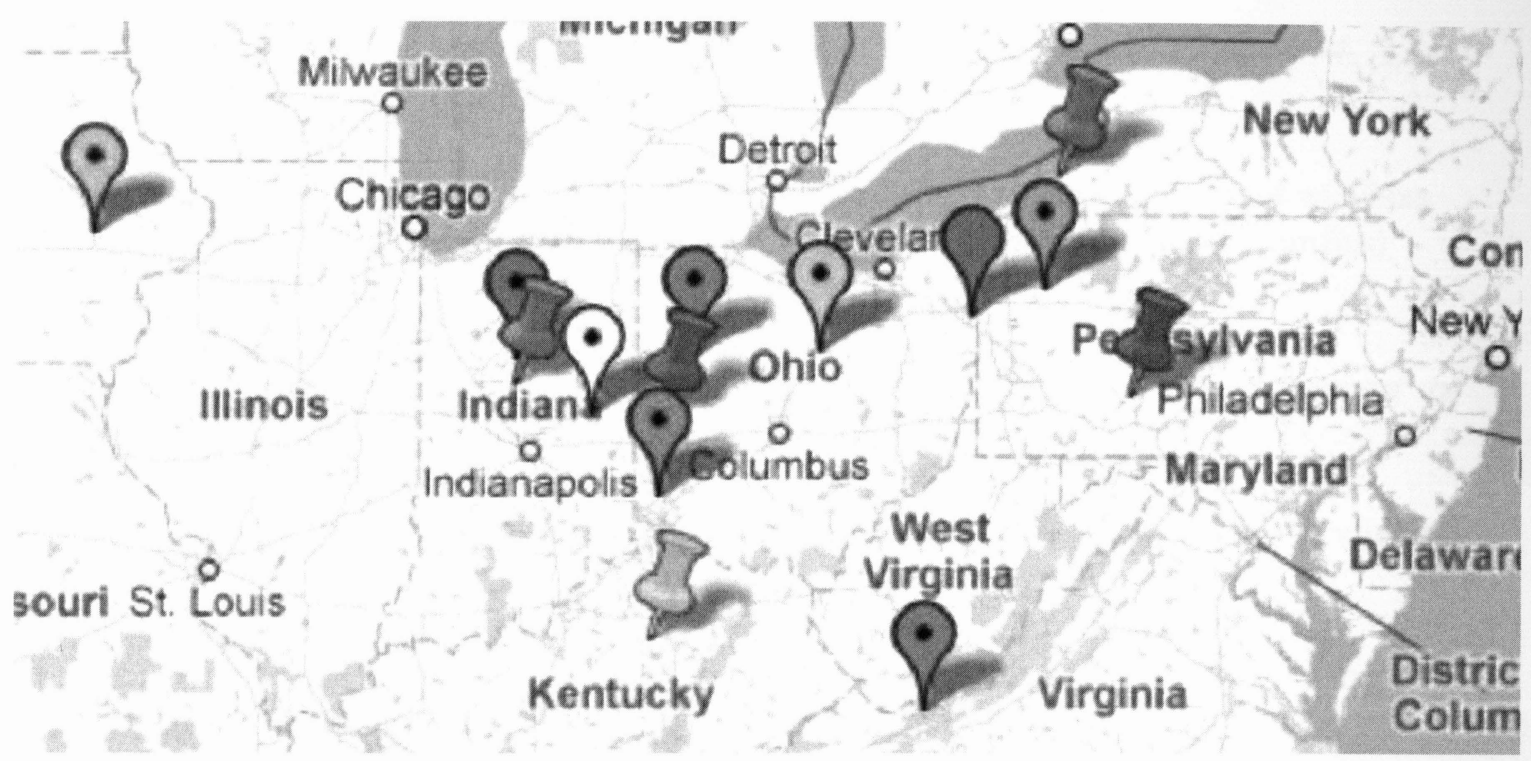

The Who Will Be Ruth Contest Map created by Jessica Whitehead available from (http://maps.google.ca/maps/ms?msid=200955518220224507901.0004a8f3e464e415651 $\underline{28 \& \mathrm{msa}=0)}$

Appendix B:

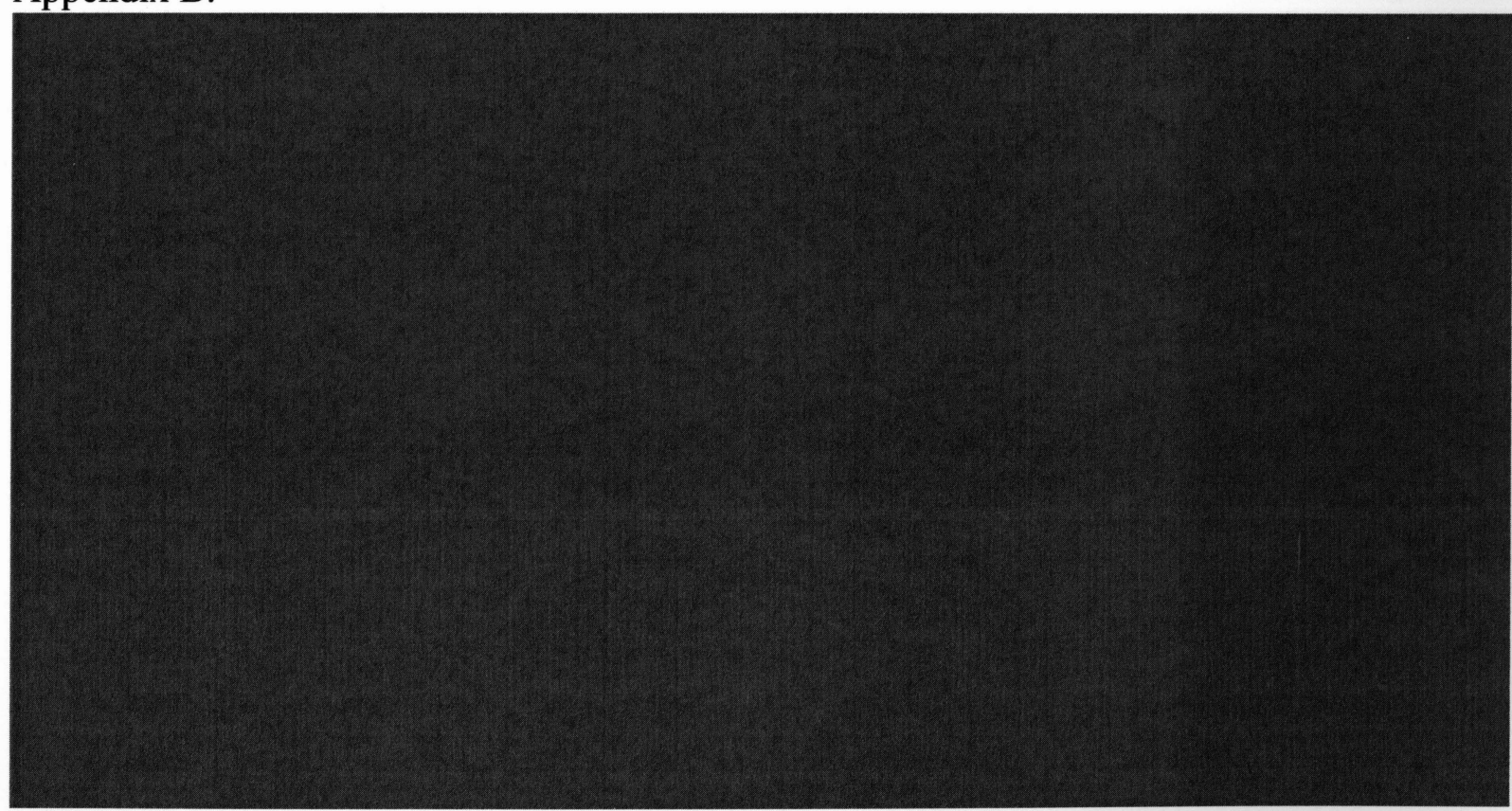

Available from Project Gutenberg (http://www.gutenberg.org/etext/16960) 


\section{Work Cited}

Abel, Richard. Americanizing the Movies and "Movie-Mad" Audiences, 1910-1914. Los Angeles, University of California Press, 2006.

Adorno, Theodor and Max Horkheimer. "The Culture Industry: Enlightenment as Mass Deception”, Dialectic of Enlightenment. Trans. Edmund Jephcott.. Stanford: Stanford University Press, 2002.

Anderson, Benedict. Imagined Communities: Reflections of Origin and Spread of Nationalism. London: Verso, 1983.

Baym, Nancy K. Tune in, Log on: Soaps, Fandom, and Online Community. Thousand Oaks, Calif.: Sage Publications, 2000.

Estad, Nan. Dressed for Adventure: Working Women and Silent Movie Serials in the 1910s, Feminist Studies, Vol. 21, No. 1 (Spring, 1995): 67-90.

Fiske, John. Understanding Popular Culture. Boston: Unwin Hyman, 1989.

Foucault, Michel. The History of Sexuality: Vol. I. New York: Vintage Books, 19881990.

Hansen, Miriam. Babel and Babylon: Spectatorship in American Silent Film. Cambridge, MA: Harvard University Press, 1991.

Keil, Charlie and Ben Singer, American Cinema of the 1910s: Themes and Variations. Newark, NJ: Rutgers University Press, 2009.

May, Lary. Screening Out The Past: The Birth of Mass Culture and the Motion Picture Industry. Oxford: Oxford University Press, 1983.

Moore, Paul, Now Playing: Early Movie-going and the Regulation of Fun: Toronto 19061918. Albany: SUNY Press. 2008.

Mulvey, Laura. "Visual Pleasure and Narrative Cinema." Screen 16, no. 3 (Autumn 1975): 6-18.

Jenkins, Henry. Textual Poachers: Television Fans \& Participatory Culture. New York: Routledge, 1992.

Jessop, B. Bringing the State Back in (Yet again): Reviews, Revisions, Rejections and Redirections. International Review of Sociology, 11, no. 2 (2001): 149-173. 
Jessop, B.. From Micro-powers to Governmentality: Foucault's work on statehood, state formation, statecraft and state power. Political Geography, no. 26 (2007): 34-40.

Lindsay, Vachel. The Art of the Moving Picture. New York: Modern Library Publishing, 2000 .

Musser, Charles. High Class Moving Pictures: Lyman H. Howe and the Forgotten Era of Traveling Exhibition, 1880-1920. Princeton, NJ: Princeton Un1versity Press, 1999.

Noyes, Dorothy. "Group." The Journal of American Folklore 108, no. 430 (Autumn, 1995): 449-478.

Singer, Ben. Melodrama and Modernity: Early Sensational Cinema and Its Contexts. New York: Columbia University Press, 2001.

Stacey, Jackie. Star Gazing: Hollywood Cinema and Female Spectatorship. London: Routledge, 1994.

Stamp, Shelly. Movie-struck girls: women and motion picture culture after the nickelodeon, Princeton, NJ: Princeton University Press, 2000.

Turner, Nancy. Having Fun With It: The Man Haters Project. Muncie, Indiana: Ball State University, 2007. 